\title{
Trade Firms Managers' Authorities in Iranian Trade Law
}

\author{
Hamideh Sadat Abtahi ${ }^{1}$, Ali Radan Jebeil ${ }^{2}$, Majid Bonakdar ${ }^{1}$, Omolbanin Darvishpoorian ${ }^{1} \&$ Gholamhossein \\ Masud $^{2}$ \\ ${ }^{1}$ Department of Private Law, Isfahan (Khorasgan) Branch, Islamic Azad University, Isfahan, Iran \\ ${ }^{2}$ Department of Private Law, College of Humanities Science, Isfahan (Khorasgan) Branch, Islamic Azad \\ University, Isfahan, Iran \\ Correspondence: Hamideh Sadat Abtahi, Department of Private Law, Isfahan (Khorasgan) Branch, Islamic Azad \\ University, Isfahan, Iran. E-mail: hsabtahi2@gmail.com
}

Received: December 23, 2015 Accepted: January 15, 2016 Online Published: March 31, 2016

doi:10.5539/jpl.v9n2p41

URL: http://dx.doi.org/10.5539/jpl.v9n2p41

\begin{abstract}
Corporate of joint-stock companies with the rule of law is done by a group of directors as the Board of Directors and the CEO assignment but corporate of other firms such conduct is not legally binding and can also pay a manager to manage them individually that this a great damage because of his individual actions contradict interests of the firms and director, he/she will be taking a personal interest and this not only for the third parties but also for partners will be susceptible to harm and great responsibilities. The studies in this paper indicate that the authorities and duties of managers in joint-stock companies in law stated separately but about the other trade, generally known as a lawyer and representative. Managers of joint-stock companies must be in accordance with the law and the resolutions of the General Assembly and the Board of Directors' decisions on corporate governance but in other trade firms, most of the managers' authorities, is general.
\end{abstract}

Keywords: Managers' authorities' limit, trade firms, partnerships companies, joint-stock companies

\section{Introduction}

Rapid technological growth and the development of great civil and commercial projects make more the need of society to joint-stock companies and with the advent of computers and new software, Corporate governance is more sensitive and because the consistency of the company's profits depend more on the state of the Board of Directors of the Company (Ebadi, 1989) has resulted in the creation of changes in terms of corporate governance. However, in the age of information and communication, success depends greatly on the amount of information a manager in the competition director of the political and economic situation of the country and the world which in turn affects the terms of corporate governance. Board of Directors has all the authorities for corporate governance and tenure of its operations except as expressly disclaims be authorized in articles of association. Board of Directors' authorities for it to be perfect should not be the general aspects, but needs some authorities to the explanations (Sotoodeh Tehrani, 2009, p. 197).

In Iran, the Articles of Association of most companies expect that all authorities in the specific matter for the Board of Directors but in European countries, Articles of Association, the Board of Directors to limit the cases in which authorities stated. Under Iranian law, Board of Directors' authorities is expected to detail and of course what also happens that the Articles of Association denies special authorities of the Board of Directors; so authorities explanation that has Board of Directors and explanation what that does not have, in Articles of Association do not have problems. Board of Directors' authorities is not related to the individual Board of Directors members but for all of them collectively and individually members of the Board of Directors unless the Articles of Association or decision of the Board of Directors is observed, has not with the authorities; so Board of Directors is responsible jointly and operating managers who are doing without the permission of the General Assembly or Board of Directors, will be responsible personally (Abtahi, 2015: 47).

Authorities of Board of Directors is to corporate and general surveillance on the Corporate Affairs and for this purpose, the Board of Directors should whenever circumstances require, Board of Directors meeting formed and give the necessary instructions to the Director or CEO for the performance of company's operations. (Article 120 L.a.q.t.) Based on the above and according to the importance of managers' authorities' limit in trade firms and how their activities in this article is the first step to authorities managers of joint-stock companies and in the second 
step, authorities of other managers of trade firms will be examined.

\section{Managers' Authorities' Limit of Joint-Stock Companies}

Legislator in the Commercial Code 1932, following the 1867 French Commercial Code on joint-stock companies, managers of joint-stock companies was deemed as a partner lawyer (Article 51 of the Commercial Code), of course, this solution is not the right solution; because firstly, managers are not shareholders' lawyer but they are company's lawyer that is a separate legal entity, secondly, with regard to the company, is an independent legal organization that the law is intended for the organization and administration and has set the duties and authorities of each of the pillars of the company, various elements of company should not deprive them of a part of the authorities of the Board of Directors. (Sotoodeh Tehrani, 2009: 197)

As a result, the Board of Directors has all of the necessary authorities for corporate governance and tenure of its operations except for authorities which is expressly denied in the Articles of Association. Board of Directors' authorities for it to be perfect should not have a general aspect, but some authorities to require explanations (Abtahi, 2015: 47).

But in Bill 1968, the legislator has abandoned this solution for managers who act as a committee, as the pillar of the pillars of joint stock companies, powers and authorities anticipated that goes beyond the scope of the attorney client (Skini, 2007 : 150);

Therefore, the Board of Directors of the Company has certain authorities is expressly in Bill 1968 is forecast, in addition to running the company also has all the necessary authorities (Article 18 of the Commercial Code adopted in 1968 a bill to amend part).

Legislative in Bill 1968, special and general authorities have been granted referred to the Board of Directors under them.

1) Invited the General Assembly

The Board of Directors is responsible for general assemblies of shareholders in deadlines set by law and when necessary also invited. President of the General Assembly if the Articles of Association or otherwise not choose or dismiss directors is not part of the agenda is the Chairman of the Board of Directors (derived from material 91 and 92 and 101 and 112 and 138 L.a.q.t).

2) Claim the unpaid amount of shares

The Board of Directors is required to collect the unpaid claim shares of all shareholders, without discrimination, within 5 years from the date of establishment of the company and to take all legal formalities related to the amount of charge remaining committed to equal shares of 35 to the reform bill is part of the Commercial Code.

3) Announce capital increase to company registration authority

The Board of Directors is obliged to declare at any time after the implementation of the capital increase by legal means, within one month shall also inform the Articles of Association in part due to the registered capital of the company registration authority to the record companies want to let the public be advertised. (Article 163 L.a.q.t).

4) Announce capital decrease to company registration authority

The Board of Directors before the General Assembly's decision to reduce capital investment reduction within one month in the official newspaper widely circulated newspaper ads related to the publication of the notice (Article 192 L.a.q.t) Also, to reduce the nominal value of shares and per share decreased amount far refused to give a statement to inform all shareholders. Company announcements shall be published in the widely circulated newspaper and sent to holders of registered shares by registered mail. (Article 196 L.a.q.t)

5) Address the issue of shares to the legal

The Board of Directors should pay legal measures to regulate and issue shares in accordance with Articles 25 and 26 L.a.q.t and also to cater to the specifications of each shareholder sells shares offices with the number of shares purchased and sample their signature holders of shares be incorporated in the book. In some companies, in addition to the Board of Directors and general assembly, council and usually decides on general topics such as regulation transactions, adoption of the budget, determining the authorized signatories be transferred to the Council. Because of the Commercial Code of several organizations that the law did not anticipate how the selection and qualifying conditions and how they will be invited to meet the provisions of Articles of Association (Sotoodeh Tehrani, 2009: 211).

6) Set a declaration form 
After checking and adjusting the layout of the balance sheet and profit and loss account the company set up under Article 110 of the Tax Code of direct declaration of 1987.12.03 is that the balance sheet and profit and loss account of the need to rely on legal offices up to four months after the tax year (usually the end of July each year) with a list of partners and stakeholders and identity in terms of the number of shares and address of each of them to the area where the residence is located now submit and pay tax. Managers to pay tax on the income of legal persons (companies) as well as tax under the provisions of law that legal entities are obliged to deduct tax directly related to the delivery of it and manage them collectively or individually with a legal personality will have liability Partnerships (Article 198 of Direct Tax Code). If the manager or managers responsible for legal persons (companies) who are refusing to perform the duties vested on submission of the declaration and the balance sheet and profit and loss account and offices and documentation would identify the individual income of less than be true extent of the be established in accordance with the documents and evidence shall be sentenced to imprisonment from three months to two years. Prosecution and proceedings against perpetrators before the courts is done by the Minister of Economic Affairs and Finance (Article 201 of Direct Tax Code). Because the guilt of those who have to deal with the financial situation and it is natural that people were not informed by the company that is in bankruptcy, will not be traded. Publication of the balance sheet and profit and loss account Company is not required by law so people can trade their informed of its contents unless the balance sheet and the profit and loss account of the company's managers request but managers are not obliged by law to provided that, for this reason, the Council of Ministers approved 1961.08.28 all companies have the balance sheet and profit and loss account your obligation to surrender the property be advertised in Official Gazette and attach a copy of the newspaper to your tax return. The interested parties can refer in each case to the balance sheet and profit and loss account of the company. If the Board of Directors doesn't do this legal obligation, guilt, and especially if the company fails to meet its obligations do managers will be personally responsible. Articles of Association of some companies predict that the company must send a copy of the attached balance sheet and profit and loss account for the invitation to the general meeting of shareholders. If this is the case in the Articles of Association is unpredictable, the Board of Directors of joint-stock companies are not at all bound to each shareholder a copy of the balance sheet and profit and loss account, but they can be part of the company's capital and balance sheet and profit and loss account and other documents personally to plan the general Assembly is prepared to take copies. Actually referring to the company's shareholders to inform of the things that have been put on the agenda in other public forums have been developed and after each meeting of the shareholders are invited to visit the company's capital and obtain the necessary information about the proposed topics.

\section{7) Save the statutory reserves or capital buffers}

According to Article 140 of the Trade Act, "Board of Directors should subject each year one-twentieth of the net profit as legal reserve. That was the legal reserve to one-tenth of the company's capital, issue it is optional and if the deduction of one-twentieth of the capital increase will continue until the legal reserve to one tenth of the capital." Issue it is optional and if the deduction of one-twentieth of the capital increase will continue until the legal reserve up to one tenth of the capital." Every year at least one twentieth of net income for the partners' capital buffers will be saved, so that capital buffers to usher the company was the subject of the content is optional. Joint-stock companies may not profit every year and as a result of various factors sometimes be faced with unpredictable losses. Joint-stock company, like all merchants will be required provisions, leaving aside such amounts as assets depreciation and amounts as doubtful receivables, it reserves the ordinary affairs of each institution, but for the strength of enterprises of the Commercial Code provides that every year $5 \%$ of the company net profit in the Save As be set aside in a timely manner possible losses recompensed to the of the Funds is loss precautionary. Supply this capital buffers until the amount reaches to tithe capital, mandatory dividend and the Board of Directors is obliged to set aside legal reserve amount. Articles of Association of the company may increase the amount of storage and the amount of what is provided for in law and in this case the duty of the Board of Directors for the purpose of storage, will be in accordance with the Articles of Association but even if the company's Articles of Association in order to reserve requirements is not provided, the Board of Directors is required to comply with the legal obligation (Sotoodeh Tehrani, 2009: 207).

8) Invited the General Assembly for the company's losses exceed half of the capital

In accordance with Article 142 of the Commercial Code reform bill: "If as a result of losses into eliminate at least half of the company's capital, the Board of Directors should immediately invite the extraordinary general meeting of shareholders will be subject to liquidation or survival of passion and vote. If the Assembly does not have the votes to dissolve at the same meeting and in compliance with article 6 of the law firm's capital to reduce the amount of capital available." Shareholders of joint-stock companies do not often get involved in the affairs of the company and its financial position is not known. Perhaps if informed that the company is profitable and its 
capital is falling regularly, to avoid wasting all your money, be present to dissolve the company to save their remaining capital. That the law has obliged trade corporation executives when the company's losses exceed half of the capital, the General Assembly invited the shareholders to discuss the liquidation of the company or continuation of the company. Amendment of Article 142 of the Commercial Code further provides: "If the Board of Directors, unlike this Article, does not attempt to call the extraordinary general meeting or a forum that invited could not be concluded in accordance with the provisions of the law, any beneficiary may request the competent court to dissolve the company." Managers should not assume responsibility for not inviting the General Assembly ends here, it should be noted that if negligence by the Board of Directors not to invite the General Assembly and all the company eliminated the possibility that managers considered responsible for the loss, because in this case the fault committed. Invited the General Assembly about the loss of more than half the company also has another benefit, because the publication of the General Assembly's agenda as a result of explanations are those that could deal with the situation of the company informed them (Sotoodeh Tehrani, 2009). Shareholders other than through the General Assembly have the right to intervene and monitor the company but it might happen that shareholders understand that the directors did not act in accordance with the interests of the company and their decision to participate or those who commit transgressions are harmful and have exceeded the limits of its authorities. If you want to wait for the annual general assembly of shareholders, the opportunity may be lost and is found to huge losses and as a result capital perished, but the owner did not want any part if a minor contribution can be requested at any time invite the General Assembly, the General Assembly entail a formal invitation and costs imposed on companies (Skini, 2007). Subject to safeguard the rights of minorities and prevent abuse of the majority in all joint-stock companies has been much discussed but no law has failed to find a solution for it because the corporation cannot be a majority of the votes of minorities and such decisions are taken by majority and minority This is when a company is accepted, unless the majority of the decisions taken ill, in which case the minority can be prosecuted in accordance with the provisions of General Manager for their fault. Articles of Association of most companies in particular Article provides that all disputes that may occur between shareholders should be brought before the General Assembly and, if the General Assembly has not approved or to pursue the dispute managers and directors of the company, any holder of shares will not have the right of recourse to the courts. The validity of such material is controversial, because if the company executives commit crimes, the General Assembly cannot prevent interested parties from going to court for compensation and demand management condemnation. When the above mentioned tasks assigned by law to the Board of Directors of joint-stock companies and the Articles of Association cannot deny the responsibility of the Board of Directors (Sotoodeh Tehrani, 2009: 209). The Articles of Association cannot predict other authorities to Board of Directors or some authorities deny them the necessary approval from the General Assembly for them. For example, the company's Articles of Association can budget to know the duties of the Board of Directors or the Board of Directors each year that explanations should bring the budget to the Assembly. It also determines who is entitled to sign on behalf of the company or have the right to borrow, accommodation, real estate transactions, etc. (Sotoodeh Tehrani, 2009).

9) Approved the company's managers and the recoupment them

Among the most important tasks of managers who are responsible for their failure to do so will result in the creation, the right to assembly and the verification and reporting of their recoupment. In joint-stock companies in the areas of corporate executives need to trust in a lawyer's sentence, so after the bills and balance sheet and profit and loss account of the company and its adoption by the General Assembly last year can claim that their actions were approved by shareholders and to establish this in the minutes of the General Assembly noted that the recoupment managers accounts have been approved by the Assembly. The shareholders in general meeting passed after the operations managers can no longer complain against managers or object to the operation and otherwise, they are responsible. If the account is valid, but the recoupment for bringing it to pass, deception and fraud resort managers are not, then there will be they civil and criminal liability, otherwise the shareholders must prove fraud and deception managers in the first stage because under Article 140 of the Commercial Code Amendment ((... any profits be divided without observing the provisions of this Act, shall be deemed fictitious profits ...)) and in Article 258 of the law states: "The following persons in custody corrections will be sentenced from one year to three years: The chairman and members of the Board of Directors and the CEO without a statement of assets and balance sheet or statement of assets and balance sheet according to hypocrisy, are divided between the imaginary interests of shareholders ..." The Annual General Assemblies and approved the company's executives after the approval of the balance sheet and profit and loss account of the company, the General Assembly requested that they be recoupment for the past year and the General Assembly considered the report of the directors and auditors and check them has to give them recoupment or the recoupment will be subject to further investigation (Sotoodeh Tehrani, 2008). 


\section{0) Company refinement}

The important task of directors of joint-stock companies, the company's refining operations. At the time of bankruptcy, the administrator who pay and the company's affairs are managed in such a way to end the operation, therefore, in accordance with Article 228 L.a.q.t. After announcing the end of treatment, the bailiff should have funds remaining in the account for the proximity of Iranian banks as creditors and shareholders who deposited and not the vindication of their rights, also submitted to the banks and even through advertisements on the same Article and Article 227 L.a.q.t to inform the interested parties have to present their quest to get to the bank. After expiration, "ten years" from the date of publication of the termination of treating any amount of funds remaining in the bank, in the sentence "without the owner's property" and on behalf of the bank and the information will be transferred to the state treasury, therefore, the city prosecutor in charge if management will not fail in this task.

\section{1) Adopted balance sheet}

In connection with the adoption of the balance sheet and profit and loss account joint-stock companies (public and private) the following is important:

1) Preparation of balance sheet and profit and loss account for each corporation is one of the important tasks of the Board of Directors shall within the period after the expiry of the fiscal year that is expected to Articles of Association of the company, assets and liabilities of the company at the end of the year and the balance sheet and profit and loss account the company's performance and the attached activity report and the general state of the financial year at least 20 days before the date of Annual General Meeting to consider and comment on the inspector or inspectors dedicated company (Article 232 L.a.q.t) and then take action to invite the General Assembly for approval and adoption of the balance sheet of the previous financial year.

2) Each shareholder may fifteen days before the conclusion of the General Assembly on the bills referred to the company balance sheet and profit and loss account and report the company's managers and inspectors report to be written. (Article 139 L.a.q.t)

3) The inspector or inspectors shall, according to the company Board of Directors, about the accuracy of financial statements and profit and loss account and balance sheet recurring billing and performance that managers prepared for submission to the General Assembly, so about content and information that managers have left public opinion and a comprehensive report of the fiscal year before the preparation and submission of their general assembly. Inspectors should be ready at least 10 days before the meeting to refer the equity in the company (derived from Article 150 L.a.q.t). In Assembly the report is to inform the shareholders present at a meeting of the Board of Directors and the company's balance sheet and profit and loss account and the report submitted to the Assembly inspector or inspector on verification measures in the areas of financial and administrative Board of Directors will be brought to the notice of members of the Assembly. Should be noted that the decision of the balance sheet and profit and loss account of the fiscal year without reading inspector or inspectors' report is not valid. (Article 89 L.a.q.t). If the inspector shall report the Assembly without the approval of the balance sheet and profit and loss account to the company, the approval does not have any legal effect and shall be void. (Article 152 L.a.q.t) as a result of the adoption of the balance sheet and the profit and loss account for each financial year and addressed to the Company to the General Assembly is normal. (Sotoodeh Tehrani, 2009: 58, 59). Board of Directors if that does not fulfill this legal obligation is to blame, and especially if the company fails to meet its obligations do managers will be responsible personally.

\section{Authorities of Other Trade Firms Managers}

However, legislative authorities and duties of the board of directors of joint-stock companies with state law, but no details about the other companies in this area is brief and succinct.

\subsection{Partnership and Relative Company}

In the case of partnerships Article 120 of the Commercial Code adopted in 1932 states that: "The partners have at least one person from your partnership or out to the manager of their choice" in Article 121 of the law "About the responsibility of the manager or managers partnership is what is stipulated in Article 51 ". In Article 51 of the Commerce Act 1932 provides: "Responsibility director of the partners is the responsibility of the lawyer to the client." To set up legal provisions cannot get around authorities and duties of the director or directors of Partnership Company what exactly are the partners who can and can only be paid to the scope of their responsibilities, with reference to the civil rules of law. The context of existing partnership firms seemed to be that if a company or Articles of Association, or the next agreement partners, some authorities have given the director about his authorities the same as it has been agreed otherwise, authorities in determining the director of the 1932 trade Act must Articles 51 and 121 of the Civil Code on corporate governance combined with the material. In this 
type of company (partnership) and also about the company relative to the reference materials 185 and 189 of the same law firm administrator in principle has all the necessary authorities for corporate governance and will not in any way responsible for damages caused by their actions, except in the case of abuse and negligence (Article 577, Civil Code). As required by corporate governance, carry out all transactions that require the subject and is in line with the interests of the company (Skini, 2008: 187). Some of these authorities are to bail out property of the company, a lawyer for the transactions, bills and bills proceeds and sales, performing a variety of sales, including credit, getting credit, marriage contracts, etc. which partners be counted in the Articles of Association authorities to please her freedom without limit which is unable to handle the company. For example, it is stated that no administrator authority to perform certain transactions or financial ceilings certain transactions, or to borrow or mortgage, circumstances considered.

\subsection{Joint-stock and Limited Partnership Company}

The company's non-stock, corporate governance principles by the partners is the host sponsor. On the contrary, partners with Limited Liability are prohibited from interfering in the running of the company. In other words, the company's non-equity partner or partners are allowed to sponsor as a manager or managers to run their company and in accordance with Article 144 of the Commercial Code 1932: "... The limits and authorities of the director that the partners have established a partnership." The office cannot be borne by the partners with limited liability and the director cannot be selected from outside the company and it seems that this is because the partners will determine Limited Liability please be imposed on partners partnership (Skini, 2008: 222). It seems that some authorities and duties of the company's non-joint stock companies shares are also complex because in Article 164 of the Commercial Code 1932 states, "The management of Joint-stock Partnership Company is for partner or sponsor partners." Article 166 of the same law also stipulated that the company should refer to the provisions of Articles 50 and 28 of the law passed in 1932. Article 50 also provides that: "To be disbursed capital funds from proven partners, have written to the director of the documentation center of the circle and gives the company is registered, declare the Names of some of the capital that has been paid to partners with a copy of the Articles of Association and one of the company a written version would be attached."

\subsection{Limited Liability Company; Ltd. Co.}

Authorities and duties of directors of limited liability companies to the Article 105 of the Commercial Code, enacted in 1932, which provides that the "authorities required to represent all company managers and corporate governance will be established unless the Articles of Association except this way, any agreement on limiting the management authorities in the Articles of Association not to explanations against third parties is null and void." The substance of paragraph 2 of Article 24 of the 1925 Act has been adapted and the commerce of France, seen signs of accepting the idea that the duties of director of business is not the same lawyer (Skini, 2008: 267). What the legislator in the case of partnership companies and has expressed relative (Articles 121 and 185 of the Commercial Code). Article 105 of the Commercial Code is not the correct translation of the French Commercial Code and Article 24 of the understanding it would be better to develop it as follows: "Except as provided in violation of the Articles of Association, company executives have all the authorities necessary to run the company. Each contract is limited to the limit on executive authorities, if they are not in accordance with the Articles of Association, to third parties is null and void." To understand the meaning of article 105 of the Commercial Code, the authorities' limitations of the director, in front of third parties and the company is mentioned.

\subsubsection{Manager Authorities for Third-Party Administrator}

Manager authorities against third parties is unlimited. Article 105 provides: "Managers will participate in all the authorities necessary for the representation and corporate governance." Here corporate governance also means doing Administration Company and the conclusion of transactions means that the administrator does the company name. In this regard, the administrator can do the most important things about the company, including the sale of property, both movable and immovable property, goodwill and authenticated transmission assets. Rule contained in Article 105 has characteristics of public order, because of the limited partners of the authorities please, after signing of the Articles of Association, have been banned. If such an arrangement is provided between the partners, to third parties will be null and void. The principle of common law on separate contracts, and therefore, the rights of third parties are well-maintained, but it does not mean that all acts of CEO, the company is committed because:

1) Article 105 is not applicable, unless the manager acted on behalf of the company.

2) The application of Article 105 is subject to the company's Articles of Association, the Articles of Association there is no limit to the manager. If the company does not have Articles of Association, only the general rules of civil law regarding the law applicable in her case, is not it the case that the provisions of Article 105. This separation of legislative Articles of Association and Articles of Association is not a case that justified 
not while we adjust the Articles of Association is not required for limited liability companies and Articles of Association is also required if there is to notice it in the newspaper.

3) Apply manager should be subject and so, authorities please just about thread is absolute, not outside it (Skini, 2008: 268).

What remains is the multiplicity of authorities in each of the directors. If the Articles of Association relating to the assumption of specific prediction, the problem does not occur, but if there is no specific provision, should assume that any manager has all the necessary authorities to operate the company and its representatives. But the interpretation of Article 105 of the Commercial Code, the opposite will be the third party materials, the opposite is in fact the situation is a matter for it.

\subsubsection{Manager Authorities for the Company and Partners}

As noted, Article 105 stipulates that participating partners, those who signed the Articles of Association, the administrator can freely determine authorities. Of course you can, during the signing of the Articles of Association of the authorities to restrict or later and later into the company with partners who have been, to make this venture. The result of this situation on the company and partners can be found on the following assumptions:

1) If the partners in the Articles of Association authorities to restrict the manager or managers, for example, predict that the binding documents must be signed by the majority of the partners, or decide not to put collateral assets, or the sale of immovable property is subject company the decision of all partners, these conditions apply in the case and if the administrator does not observe them, the company and the partners will be responsible for carrying out these obligations, but the manager is responsible.

2) If the Articles of Association of the authorities to be quiet please, please have absolute authorities, provided that a separate agreement between the partners and the manager, authorities did not restrict him. In other words, authorities can restrict the administrator about the company and partners under private contract, in which case, if the contract is manager of some authorities, will be responsible for the company and partners, but with that, on the premise, not the Articles of Association, is void against third parties (Skini, 2008: 264).

\subsection{Cooperative Production \& Consumption Company}

In the case of Cooperative Production \& Consumption Company Act of 1991 cooperation of authorities and duties of the board of directors was given in detail. According to Article 37 of the Cooperative Code of authorities and responsibilities include: invited the General Assembly, the implementation of the Articles of Association and decisions of the General Assembly and other relevant provisions, the appointment and dismissal and resignation of the managing director, overseeing operations and offered him the CEO of the General Assembly accept the membership application, the decision to transfer Member contributions to each other, Get the resignation of any member of the Board of Directors, monitor current expenditures cooperative, handle billing and provide the inspector or inspectors, addressing timely submission of financial reports and balance sheet to the General Assembly, preparation and management of projects and programs and budgets and other proposals and submit it to the General Assembly, appoint a representative for the company and unions that participated in the cooperative, internal guidelines, legal representation of the cooperative, to nominate authorized signatories and doing other authorities and duties under the provisions of Articles of Association.

\section{Conclusion}

In joint-stock companies, legislator, has innovations that the advantage of this law to the Commercial Code adopted in 1932 to determine the duties and authorities that certain directors of joint-stock companies are listed separately but in the case of other commercial companies, as a whole, such as lawyers and members is known. Managed investment companies, especially joint-stock companies, because of the importance of investment in these companies, considered by the legislature more than companies' entities including partnerships and relative, is the precise configuration. Unfortunately, the law on corporate governance entities and their managers contracts and transactions not laws, jobber and managers in terms of personal gain from this outline law, with the formation companies such as the Limited Liability Company; Ltd. Co., in the ambit of the Act, attempted money laundering and fraud and has benefited their pockets and the run will be a great investment opportunity and make the country the economic cycle that causes inflation in society and damage to refer low-income and distrust of managers and as a result the entry will be irreparable damage to the economy. The brevity of the law on commercial companies and gripped not only involves the loss or damage to third parties, partners and managers. In a general partnership precisely because of liability partnership, the offender manager remains open to abuse. Investors and partners are companies relative exception because although these companies are limited liability partners in proportion to their investment, however, if the amount of debt due to significant mismanagement of 
managers is often too so, the responsibility value of partners also will be noticeable. In joint-stock companies with a surveillance system that governs how managers in corporate governance, again due to lack of the required laws, managers pay to abuse credit and company information and transactions profitable for the company coverage, attempt to gain illegal and at the same time because of the law to subscribe to a commercial company as $\mathrm{CEO}$ and member of the Board of Directors of commercial companies, is provided by the administrator regard to personal abuse. It should also be added that in any business, if you please violators with improper management company, is causing distress to third parties, even if a company or partners, be sufficient to pay all debts, because of the long process of justice in our country, months or even years it takes to rule and voting records, issued and the executive. As a result, even if the creditors, with all its demands, including the rate of inflation and the cost of the hearing and receive, again because of their capital remain blocked for the duration of the proceedings, be entitled to a non-profit, because the people who foot the economy work, be sure to investments in economic turnover, accurate financial planning and stagnation, and with a strong capital loss that, of course, loss of profit them or cannot claim or prove that it is hardly possible. Corporate joint-stock companies by law, must be done by a group of directors as the board of directors and the managing director of other companies such law does not require the assignment and can also pay an individual to manage their own great harm because of his individual actions contradict interests of the firms and director, he/she will be taking a personal interest and this not only for the third parties but also for partners will be susceptible to harm and great responsibilities.

\section{References}

Abtahi, H. S. (2015). Compare with other joint-stock companies with other Trade Firms of Iranian Trade Law, Master's thesis, Faculty of Law, Islamic Azad University of Khorasgan Branch, Isfahan.

Ebadi, M. A. (2013). Trade Law (33th ed.). Ganje Danesh: Tehran.

Erfani, M. (1983). Public Joint Stock Company, Public Held Co. And Private Joint Stock Company, Private Held Co., Farhang Publications: Tehran.

Paseban, M. (2010). Trade Firms Laws (4th ed.). Samt Publications: Tehran.

Rabia, S. (2007). Trade Law and Trade Firms (Vol. 1, 11th ed.). Samt Publications: Tehran.

Rabia, S. (2008). Trade Law and Trade Firms (Vol. 2, 11th ed.). Samt Publications: Tehran.

Rabia, S. (2010a). Trade Law and Trade Firms (Vol. 1, 11th ed.). Samt Publications: Tehran.

Rabia, S. (2010b). Trade Law and Trade Firms (Vol. 2, 11th ed.). Samt Publications: Tehran.

Sotoodeh Tehrani, H. (2009). Trade Law (vol. 1, 16th ed.). Dadgostar Publications: Tehran.

\section{Copyrights}

Copyright for this article is retained by the author(s), with first publication rights granted to the journal.

This is an open-access article distributed under the terms and conditions of the Creative Commons Attribution license (http://creativecommons.org/licenses/by/3.0/). 